\title{
Perancangan Sistem Informasi Traceability Produk Pangan Halal UKM Unggulan Berbasis Digital Business Ecosystem
}

\section{An Analysis And Design for SME Halal Food Product Traceability Information System Based on Digital Business Ecosystem}

\author{
Aditia Ginantaka1a, Endrianur Rahman Zain'1 \\ ${ }^{1}$ Jurusan Teknologi Industri Pertanian Fakultas Ilmu Pangan Halal Universitas Djuanda \\ Bogor, Jl. Tol Ciawi No. 1, Kotak Pos 35 Ciawi, Bogor 16720. \\ aKorespondensi: Aditia Ginantaka, E-mail: aditia.ginantaka@unida.ac.id
}

(Diterima oleh Dewan Redaksi: 26-09-2017)

(Dipublikasikan oleh Dewan Redaksi: 25-10-2017)

\begin{abstract}
Halal foods are those that do not contain elements of food that are prohibited to consume by Muslims, both of raw materials or food ingredients. Traceability is one of requirement on halal assurance system which arranged by LPPOM MUI Indonesia. Consumers could obtain information about the origin of all input materials for food products based on one step forward and one step back at any sphere in the supply chain, by utilized traceability system. This paper aims to analyze the requirement and to design of traceability system that could capture all relevant data with halal standard food production processes. The development of traceability system on digital business ecosystem (DBE) base replaces all process documentation by using paper (paper based), thus resulting paperless document. Based on requirement analysis, this system composed by 4 stakeholder for instance, production unit and logistic unit by SME, consumer and website admin. The database structure composed by the type of raw material, transportation of raw materials handling standards, supplier origin, destination of distribution store.
\end{abstract}

Keywords: traceability, halal food, information system

\begin{abstract}
ABSTRAK
Makanan halal adalah sesuatu yang tidak mengandung bahan yang dilarang untuk dikonsumsi oleh orang muslim baik pada bahan baku maupun bahan tambahan. Traceability merupakan salah satu standar dalam sistem jaminan halal yang disusun oleh LPPOM MUI Indonesia. Konsumen dapat menggunakan system traceability untuk memperoleh informasi mengenai asal dari semua bahan baku yang digunakan untuk menghasilkan produk pangan. Baik satu tahap sebelumnya maupun satu tahap sesudahnya dalam mekanisme sistem rantai pasok. Penelitian ini bertujuan untuk menganalisis kebutuhan dan merancang system traceability yang dapat mendokumentasikan semua data yang relevan berdasarkan standar produksi pangan halal. Berdasarkan analisis kebutuhan sistem ini terdiri dari empat stakeholder diantaranya unit produksi dan unit pengiriman pada UKM, konsumen dan admin website. Sistem berbasis digital business ecosystem dapat menggantikan proses dokumentasi berbasis kertas (papper based) sehingga menghasilkan dokumen paperless. Database sistem berisi data yang berkaitan dengan bahan baku, standar penanganan bahan dan transportasi, asal pemasok, tujuan distribusi. Setiap data disimpan dengan sistem keamanan tinggi untuk menghindari kehilangan data dan dapat dipindahkan kepada stakeholder lain menggunakan website.
\end{abstract}


Kata kunci: traceability, pangan halal, sistem informasi

Ginantaka A. 2017. Perancangan Sistem Informasi Traceability Produk Pangan Halal UKM Unggulan Berbasis Digital Business Ecosystem. Jurnal Agroindustri Halal 3(2): 170 - 182.

\section{PENDAHULUAN}

Traceability merupakan kemampuan untuk menyajikan informasi berkaitan dengan riwayat dan perpindahan sebuah barang/benda melalui setiap tahapan proses produksi dan distribusinya. Sistem ini mengharuskan pelaku rantai pasok mengetahui siapa yang memasok ke perusahaan dan kepada siapa produk dikirimkan, sehingga masing-masing aktor memiliki akses informasi baik ke arah hulu (upstream) maupun ke arah hilir (downstream) (Bosona dan Gebresenbet 2013; Mgonja et al. 2013). Sistem ini memungkinkan untuk dilakukannya eliminasi terhadap produk pangan yang tidak memenuhi syarat keamanan pangan dari sistem rantai pasoknya, serta mengatur kondisi lingkungan yang mempengaruhi safety dari produk. Sebagai salah satu kriteria sistem jaminan halal dari LPPOM MUI sistem Traceability mampu memberikan jaminan bagi konsumen untuk melakukan verifikasi terhadap standar halal produk pangan (Bennet 2010).

Sebuah produk pangan dinyatakan halal jika tidak mengandung unsur-unsur makanan yang dilarang untuk dikonsumsi oleh umat Islam, baik dari bahan baku atau dari bahan komposisi penyusunnya. Saat ini kebutuhan sistem Traceability tidak hanya dilatarbelakangi oleh meningkatnya perhatian konsumen dan pemerintah terhadap keamanan pangan (food safety), kesehatan (food hygiene) dan keaslian produk pangan (food authenticity) (Furness dan Osman 2006), melainkan juga terkait dengan standar kehalalan yang ditetapkan oleh otoritas

organisasi islam milik pemerintah dari suatu negara. Sistem Traceability merupakan aspek penting bagi perusahaan yang ingin memasuki pasar global. Sebagai salah satu standar untuk memperoleh sertifikat halal, sistem Traceability sangat penting bagi para eksportir agar tidak mengalami penolakan dari negara importir. Ditambah lagi dengan semakin tingginya ketertarikan konsumen muslim terhadap asal usul produk pangan sebagai bagian dari pemenuhan kewajiban terhadap ajaran islam berkaitan dengan aturan dalam mengkonsumsi makanan (Zailani et al. 2010).

Rantai pasok produk pangan halal perlu dibangun secara sistematis dalam merespon kebutuhan konsumen dengan kemampuan kordinasi setiap unit bisnis pelaku rantai pasok. Partisipasi dari setiap pelaku rantai pasok sangat dibutuhkan untuk menjadikan sebuah produk pangan mampu ditelusur (traceable) sehingga sistem ini mampu menjamin asal dari produk pangan halal. Sistem Traceability diimplementasikan sebagai bentuk kemampuan pengendalian resiko terhadap temuan produk atau bahan makanan yang belum terjamin kehalalannya. Traceability pada produk pangan halal bertujuan untuk menjamin pemenuhan standarisasi halal pada seluruh tahapan produksi, transportasi dan distribusi (Shafii dan Khadijah 2012). Oleh karena itu, diantaranya informasi yang perlu dipenuhi meliputi jenis atau tipe bahan baku, asal pemasok, prosedur mengenai penanganan bahan baku dan proses pembuatan produk, informasi tentang lokasi pusat distribusi, standar penanganan transportasi bahan baku hingga metode penanganan saat pengiriman produk untuk mencegah kontaminasi terhadap produk non-halal.

Zailani et al. (2010) menjelaskan tentang studi akan pentingnya 
Traceability dalam rantai pasok, diikuti dengan kondisi terkini tentang efektifitas sistem Traceability dan penjelasan tentang tujuan sistem Traceability serta sitem tracking produk halal terutama untuk produk peternakan di Malaysia. Sistem Traceability halal akan meningkatkan transparansi pada rangkaian tahapan produksi produk pangan. Adanya transparansi dapat meningkatkan kepercayaan konsumen terhadap kehalalan produk pangan karena konsumen dapat mengakses informasi yang jelas diantara para pelaku rantai pasok produk berkaitan dengan proses produksi dan kontrol terhadap keamanan pangan. Shafii dan Khadijah (2012) menjelaskan bahwa secara tidak langsung sistem Traceability telah berdampak positif pada pemulihan reputasi perusahaan, citra terhadap merek dan kepercayaan konsumen muslim pada komposisi produk. Sistem penelusuran (trace) terhadap kualitas kehalalan pada keseluruhan tahapan produksi juga telah diterapkan pada industri daging sapi Tiongkok (Yang dan Bao 2010).

Melalui sistem Traceability perusahaan mampu mengidentifikasi lot produk dan hubungannya dengan batchbatch bahan baku, proses, dan pengiriman produk, sehingga tidak perlu dilakukan penarikan terhadap seluruh lot produk yang diproduksi. Disamping itu, sistem Traceability juga menjadikan perusahaan memiliki keunggulan kompetitif melalui kemampuan untuk mendokumentasikan karakteristik produk (Olsen dan Borit 2013). Benefit yang dimunculkan dari sistem Traceability ini dapat menjadi alasan bagi perusahaan untuk menerapkan sistem Traceability dan tidak sekedar didorong oleh kepatuhan terhadap peraturan yang diterapkan oleh beberapa negara importir.

Salah satu tantangan terbesar dalam pengembangan sistem Traceability adalah bagaimana melakukan pertukaran data antar pelaku rantai pasok serta menyajikan informasi dalam format standar (Thakur et al. 2010; Hu et al. 2013). Untuk tujuan tersebut sistem Traceability membutuhkan dukungan perangkat berbasis teknologi informasi (TI) untuk mendukung proses pengumpulan, penyimpanan dan akses terhadap data. Perkembangan teknologi informasi telah mampu mendorong adanya perubahan dalam dokumentasi manual (paper-based) menjadi dalam bentuk digital. Digital business ecosystem (DBE) merupakan sebuah representasi dari sebuah ekosistem bisnis (business ecosystem) dimana setiap pelaku bisnis saling berinteraksi dalam lingkungan digital (Nachira et al. 2006). Salah satu bentuk ekosistem digital dapat diwujudkan dalam bentuk website. Produk pangan UKM unggulan dengan potensi ekspor dapat menjadi sumber pendapatan potensial bagi pelaku usaha di Indonesia. Oleh karenanya pengembangan sistem Traceability berbasis DBE sangat diperlukan untuk semakin meningkatkan kepercayaan importir terhadap produk pangan UKM unggulan Indonesia.

Tujuan penelitian ini adalah melakukan analisis kebutuhan dalam bentuk business process analysis dalam sistem Traceability, mendesain komponen, aturan, peran dan mengintegrasikan komponen sistem informasi manajemen Traceability pada produk bersertifikasi halal dari UKM unggulan dan memverifikasi dan memvalidasi sistem untuk mengevaluasi performa sistem informasi Traceability.

\section{METODOLOGI}

Proses desain sistem mengikuti mekanisme yang ditetapkan dalam system development life cycle (SDLC), meliputi requirement analysis, design and development, testing and evaluation. Tahapan dalam SDLC ditunjukan pada Gambar 1. 


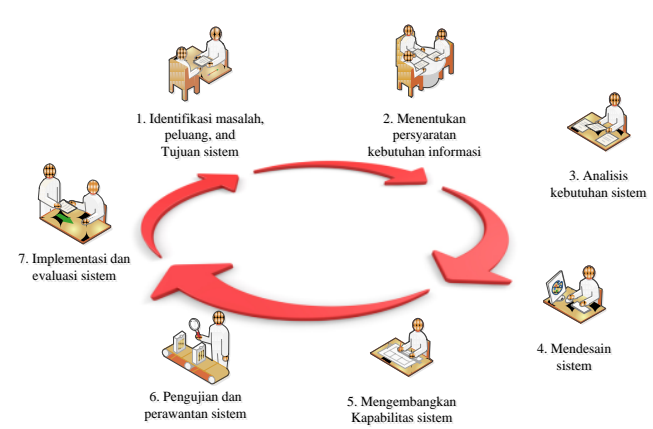

Gambar 1. Sistem Development Life Cicle

(Kendall dan Kendall 2006)

1. Identifikasi Komponen Sistem

Komponen sistem diidentifikasi dengan metode observasi, wawancara mendalam dan pengisian kuisioner. Proses observasi dan penyebaran kuisioner dilakukan kepada pelaku UKM untuk memperoleh atribut data terkait proses produksi. Wawancara ditujukan kepada lembaga yang berwenang seperti LPPOM MUI saat melakukan proses audit halal dan pemeriksaan standar sistem jaminan halal. Setelah semua data dan informasi diperoleh, dilakukan analisis kebutuhan sistem dalam matriks requirement. Alur kerangka pemikiran dapat dilihat pada Gambar 2.

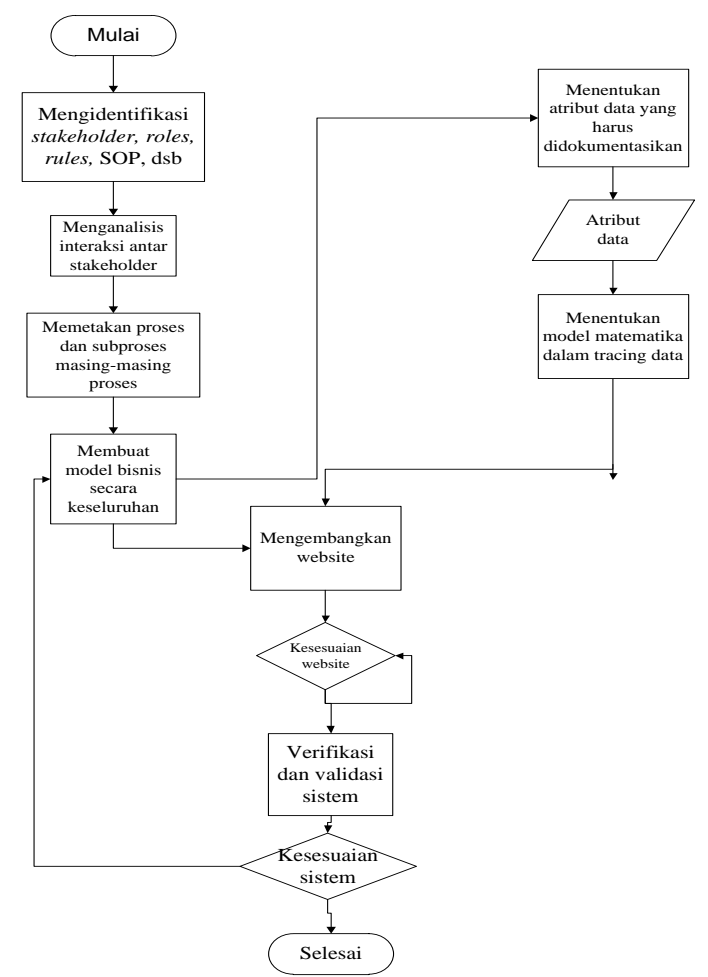

Gambar 2. Kerangka Metode Penelitian
Secara detail komponen penyusun sistem terdiri dari berbagai atribut yang meliputi input yang diinginkan/tidak diinginkan, stakeholder, peran, sumber daya, kontrol, ouput yang diinginkan/tidak diinginkan. Konsep arsitektur sistem, menjelaskan bahwa analisis sistem merupakan langkah untuk mengurai sistem menjadi komponen penyusunnya. Kerangka analisis meliputi pengamatan bagaimana berinteraksi dengan dirinya sendiri dan lingkungan operasionalnya. Langkah ini membuat kita mampu mengkarakterisasi System of Interest dan lingkungan operasionalnya melalui elemen-elemen penyusun sistem.

\section{Analisis Bisnis Proses}

Analisis mekanisme proses bisnis dilakukan menggunakan BPMN (business process model and notation). Output dari analisis ini yaitu dapat diidentifikasi stakeholder yang terlibat, peran masingmasing stakeholder, aturan dalam proses bisnis, aliran data dan sebagainya yang dapat mendukung operasionalisasi dari sebuah aktivitas bisnis. BPMN dibuat dengan menggunakan software PowerDesigner ${ }^{\circledR}$ versi 16.1. Notasi dalam BPMN dibuat dalam "swimlane" yang digunakan untuk membantu membuat penyekat dalam mengatur aktivitas pada diagram BPMN. Pembuatan BPMN dilakukan dengan mengkombinasikan beberapa notasi seperti pada Gambar 3 .

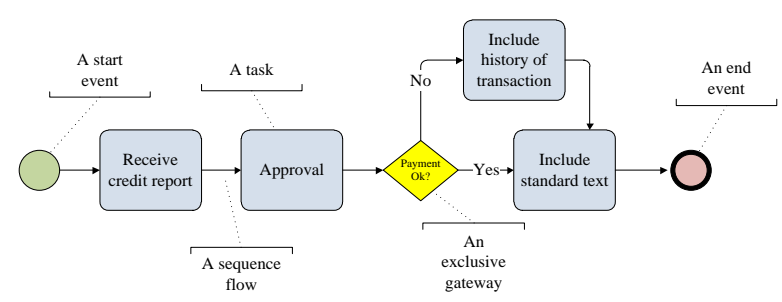

Gambar 3. Contoh proses yang digambarkan dalam BPMN (White and Miers 2008) 
3. Model Website Pendokumentasian Data dan Proses Penelusuran (Tracing)

Basis dari desain sistem informasi berada pada bagaimana mendesain sistem perolehan data dan informasi (information acquiring) sehingga dihasilkan sebuah database dengan informasi yang cukup dan lengkap (Lei dan Wen-li 2012). Oleh karenanya pada penelitian ini aplikasi dikembangkan dengan bahasa pemrograman Ruby atau NodeJS sebagai basis perancangan website. Dimulai dengan menentukan domain dan hosting website, selanjutnya dilakukan pengaturan terhadap fitur website. Proses transformasi input menjadi output dalam sistem Traceability secara sederhana digambarkan pada Gambar 4.

\begin{tabular}{|c|c|c|}
\hline $\begin{array}{l}\text { Input } \\
\text { - Data } \\
\text { Produk } \\
\text { - Data } \\
\text { Proses } \\
\text { - Data } \\
\text { Kualitas } \\
\text { Produk }\end{array}$ & \begin{tabular}{|l} 
Entitas Sistem \\
- Pengisian \\
formulir data \\
produk oleh \\
setiap \\
stakeholder \\
- Input data dalam \\
database \\
- Transfer data \\
antar stakeholder \\
- Tracing Data
\end{tabular} & $\begin{array}{l}\text { Output } \\
\text { - Informasi } \\
\text { produk yang } \\
\text { relevan } \\
\text { sesuai ID } \\
\text { Produk } \\
\text { - Laporan } \\
\text { Tracing } \\
\text { Produk }\end{array}$ \\
\hline
\end{tabular}

Gambar 4. Bagan input-proses-output sistem

\section{Verifikasi dan validasi}

Kesesuaian terhadap kebutuhan sistem dan metode verifikasinya didokumentasikan dalam requirement verification matrix (RVM) (Wasson 2006). Metode inspeksi digunakan untuk membuktikan apakah logika sistem telah diimplementasikan secara benar atau tidak. Proses verifikasi juga dilakukan untuk memeriksa kelengkapan dan kesesuaian fungsional dari website. Proses validasi dilakukan menggunakan metode wawancara dan simulasi penggunaan website dengan metode pengujian black box.

\section{Pelaporan}

Proses penyajian laporan hasil dokumentasi data produk dilakukan pada setiap traceable unit menurut waktu dan tipe isi laporan. Informasi yang terdapat dalam pelaporan meliputi (1) deskripsi dari produk, (2) waktu kadaluarsa produk dan (3) diagram alir proses produk, yang dilengkapi dengan informasi ID yang digunakan selama proses produksi, informasi waktu kejadian pelaksanaan proses, informasi parameter mutu proses serta ukuran similarity produk pada setiap rantai proses dan durasi pencarian / tracing.

Penelitian ini dilakukan di Kabupaten/Kotamadya Bogor dengan mengambil model UKM produk pangan unggulan kabupaten Bogor yang sudah tersertifikasi halal. Analisis bisnis proses dilakukan di Laboratorium Komputer Kampus UNIDA Bogor. Alasan pemilihan UKM di Kabupaten/Kotamadya Bogor adalah (1) mudah mengakses narasumber dan stakeholder dari LPPOM MUI pusat dan Pemerintah daerah serta pelaku UKM, (2) ketersediaan sarana dan jaringan internet yang memadai (3) UKM yang dipilih berbasis wilayah sehingga diharapkan proses uji coba sistem dapat dilakukan dengan mengambil sampel konsumen pada wilayah setempat yang menjadi pelanggan UKM.

\section{HASIL DAN PEMBAHASAN}

\section{Identifikasi Komponen Sistem}

Komponen sistem diidentifikasi berdasarkan hasil observasi dan wawancara kepada UKM. Wawancara dilakukan kepada pemilik UKM atau bagian produksi berdasarkan pertanyaan pada kuesioner. Observasi dilakukan kepada tiga pelaku usaha UKM di Bogor diantaranya Fadhilah Snack, Sari Pakuan, dan Krisa Snack. Berdasarkan hasil observasi diketahui bahwa UKM Fadillah dan Krisa tidak melakukan proses pendokumentasian data dan pencatatan data proses produksi. Pencantuman informasi pada label produk belum mendukung proses traceability produk, sebagai contoh seperti pencantuman kode 
produk. UKM Fadillah Snack dan Krisa Snack hanya mencantumkan label nama produk dan info nomor telepon produsen. Sementara Sari Pakuan sudah melakukan pencatatan data penting dan pada label kemasan tercantum identitas kode produk, informasi nomor telepon, dan tanggal kadaluarsa. Secara umum, belum ada UKM yang melakukan pencatatan pada proses produksi. Pencatatan hanya dilakukan untuk mendata penjualan produk. Kegiatan kunjungan kepada UKM ditunjukan pada Gambar 5.

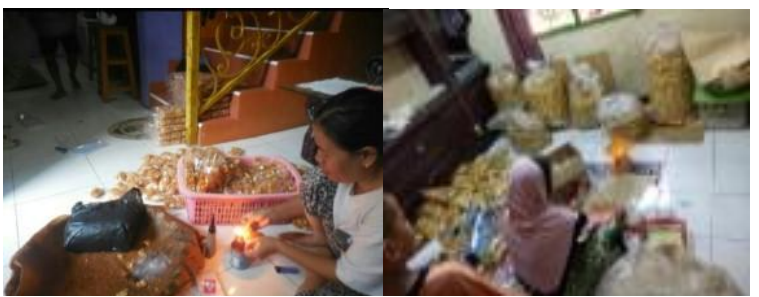

(a)

(b)

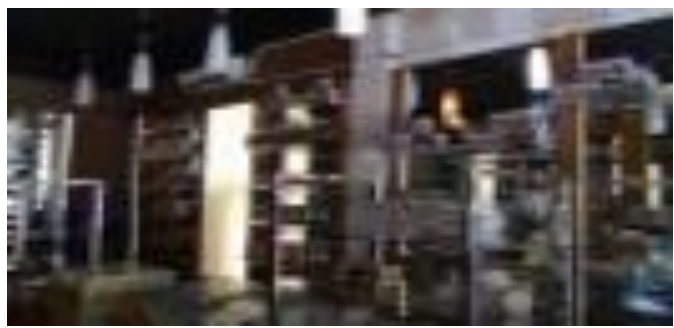

(c)

Gambar 5. Foto Kunjungan ke UKM (a) Fadhilah Snack, (b) Krisa Snack, (c) Sari Pakuan

Hasil observasi menunjukan bahwa UKM dengan skala usaha yang relatif besar sudah memiliki kesadaran akan pentingnya proses pendokumentasian dan pencatatan proses produksi. Hal ini ditunjukan pada UKM sari pakuan yang memproduksi Makanan seperti brownies, bolu, kue lapis talas dan sebagainya. Bagi UKM Fadhilah snack dan Krisa Snack skala produksi yang masih rendah dan jangkauan pemasaran produk terbatas menjadikan proses pendokumentasian dan pencatatan tidak terlalu dibutuhkan. Pencatatan data proses produksi saat ini belum dapat dilaksanakan dengan baik
Karena keterbatasan SDM dan pemasaran yang tidak menentu. Penerapan sistem pencatatan akan menimbulkan biaya tambahan untuk operator pencatatan. Hal ini sejalan dengan yang disampaikan Scheer (2006), yang menjelaskan bahwa sistem traceability tidak memberikan efek pada efisiensi biaya dan peningkatan nilai tambah produk, melainkan untuk kepentingan sertifikasi produk. Secara umum bisnis proses yang saat ini dilakukan oleh UKM ditunjukan pada Gambar 6.

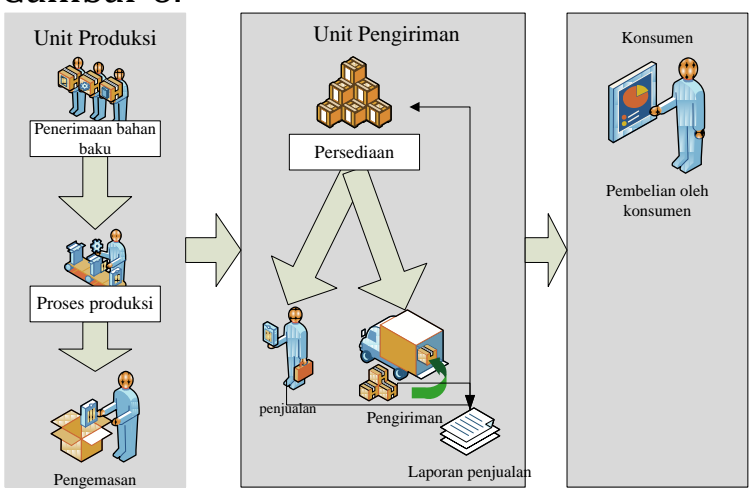

Gambar 6. Bisnis proses saat ini yang dilakukan UKM

Hasil analisis kebutuhan menunjukan bahwa sistem traceability melibatkan empat stakeholder. Stakeholder tersebut diantaranya adalah UKM sebagai pengguna I (user I) sistem traceability yang terdiri dari stakeholder unit produksi dan unit pengiriman, stakeholder admin website dan terakhir adalah konsumen pembeli produk UKM sebagai pengguna II (user II). Masingmasing stakeholder memiliki peran untuk mencapai tujuan sistem. Hasil analisis kebutuhan sistem berbasis pada peran dan misi yang harus dicapai oleh setiap stakeholder kemudian diikuti dengan proses untuk untuk mencapai misi sistem. Berdasarkan hasil analisis peran dan proses yang terjadi dalam sistem kemudian diidentifikasi kebutuhan data dan penggunaan sumber daya untuk mendukung peran setiap stakeholder.

\section{Analisis Bisnis Proses.}


Bisnis proses dalam sistem traceability dimodelkan dalam BPMN 2.0. Berdasarkan analisis kebutuhan Setiap stakeholder melakukan proses dokumentasi ke dalam aplikasi input data dengan cara mengakses laman website melalui komputer desktop di masingmasing unit stakeholder. Sebagai sebuah sistem sistem traceability harus memenuhi arsitektur dasar sistem seperti yang dijelaskan oleh Wason (2006) yang meliputi detail komponen bagan inputoutput seperti yang ditunjukan pada Gambar 7.

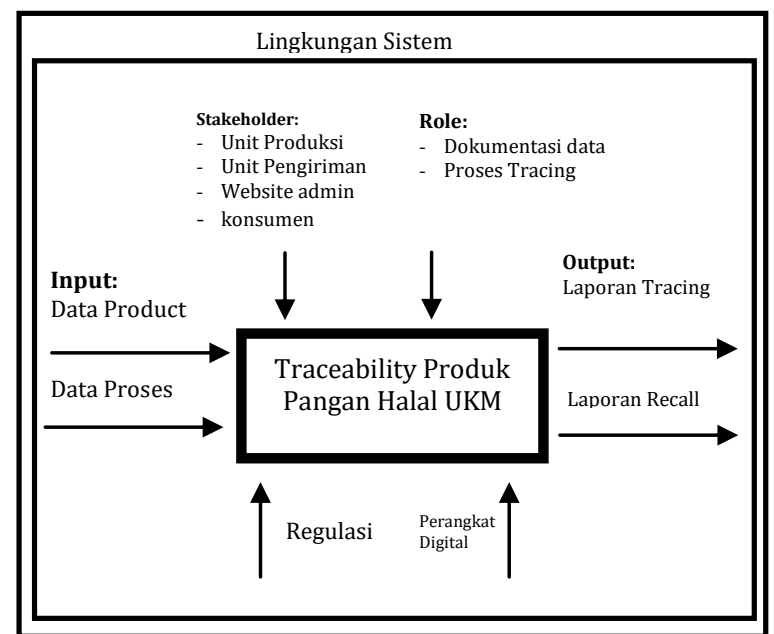

Gambar 7. Skema input-output data dan informasi dalam website sistem traceability produk pangan Halal UKM

Sebagai contoh pada unit produksi. Atribut data yang didokumentasikan diantarannya ID produk, nama produk, ID bahan baku, ID Suplyer bahan baku yang diberikan, ID line/Batch. Seluruh atribut data didokumentasikan selama aktivitas proses produksi. Gambar bisnis proses tahap dokumentasi data pada unit produksi dapat dilihat pada Gambar 8.

Tahapan dokumentasi pada unit produksi ini dimulai dengan pengisian formulir data produksi dengan lengkap, setelah data lengkap operator pada unit produksi dapat dilakukan masukan (input) data ke dalam Sistem website. Akses kedalam website dilakukan setelah melalui tahap log masuk (log in). Apabila data produksi telah selesai dimasukan selanjutnya maka tahap pengisian data produksi dianggap selesai. Tahapan bisnis proses pada unit produksi berakhir ketika produk sudah terkemas. Setelah seluruh data terdokumentasi, sistem perlu melakukan generate label kemasan yang berisi rangkaian kode unik ID produk untuk ditempelkan pada kemasan.

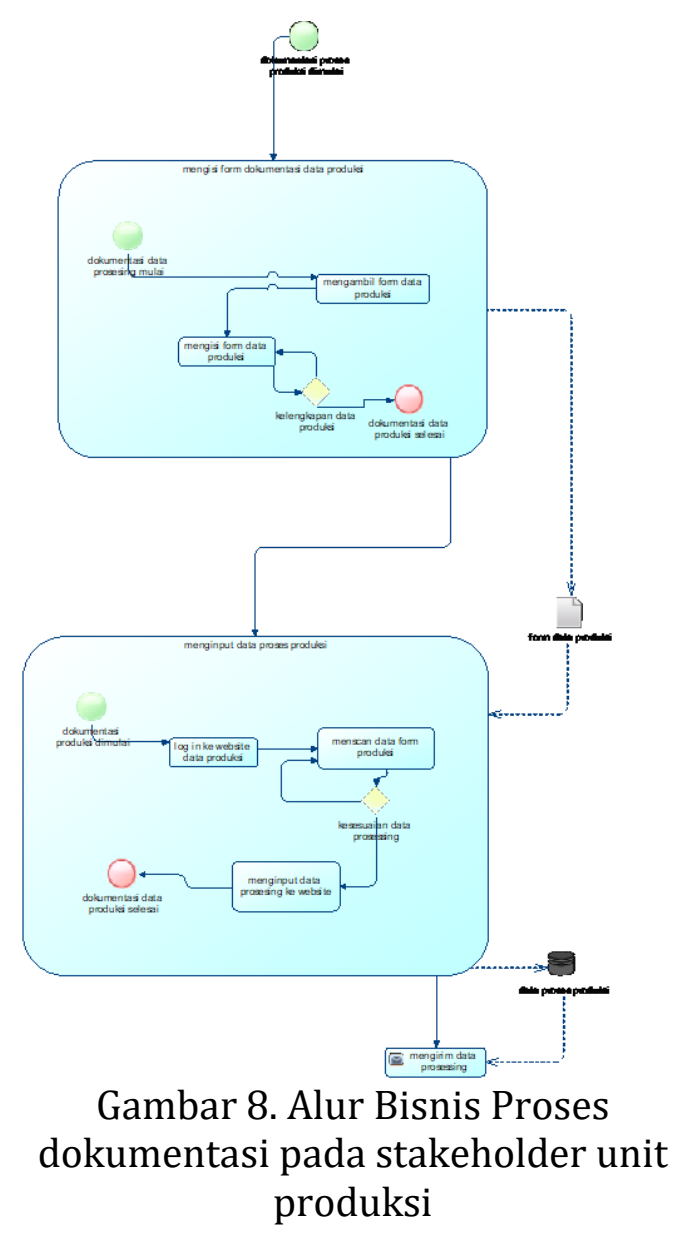

Setiap proses input data dilakukan di akhir proses penanganan produk, karena selama penanganan produk dilakukan dokumentasi data yang terkait dengan rekam jejak produk ke tahap proses selanjutnya. Setiap stakeholder melakukan proses yang sama yaitu proses input data dalam formulir dan input kedalam komputer desktop untuk disimpan dalam server website. ID produk yang dicetak dalam label kemasan menjadi kunci untuk registrasi produk 
yang ditangani. Bentuk label yang berisi ID dapat berupa barcode atau QR-code. Proses identifikasi informasi ID produk pada sistem dilakukan dengan memindai kode menggunakan perangkai pemindai (scanner) kode (Gambar 9). Setelah proses pemindaian kode produk terbaca dalam komputer beserta data yang telah didokumentasikan. Aplikasi pada stakeholder lainnya digunakan untuk menginput data-data yang didokumentasikan dalam proses produksi berikutnya. Hasil dokumentasi data pada unit produksi akan tersimpan dalam data base.

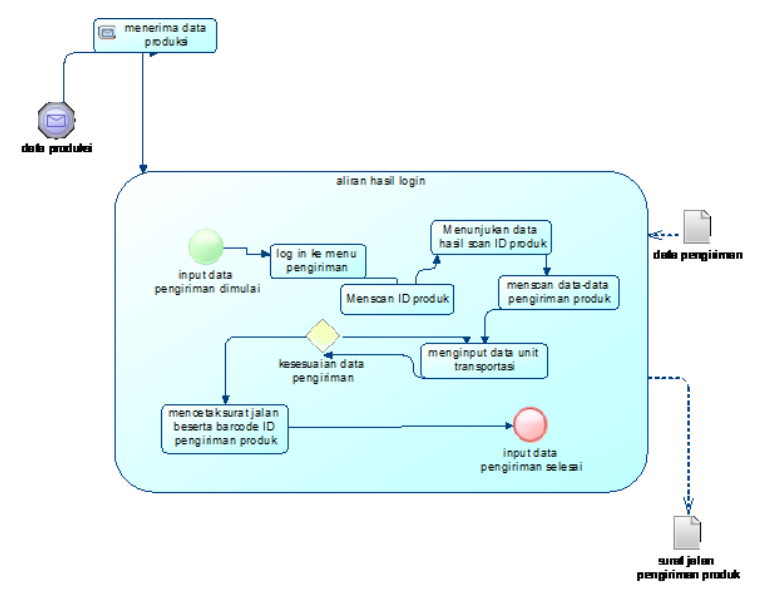

Gambar 9. Tahapan pembacaan data dengan pemindai (scanner)

Proses pelacakan (trace) informasi produk merupakan proses retrieval data yang telah disimpan dalam data base dalam aplikasi antar muka (interface) pengguna. Sistem traceability digunakan oleh stakeholder konsumen (user II) untuk menampilkan semua informasi berdasar kode unik dari ID produk. Tahapan pelacakan data produk dilakukan dengan menggunakan interface mesin pencari (search engine) pada website. Tahapan retrieval informasi pada proses pelacakan dilakukan oleh sistem dengan melakukan proses pengurutan data, pencarian dan pengukuran similarity data dari kode ID produk yang dimasukan. Tahapan bisnis proses pada tahapan tracing berakhir setelah semua informasi ditampilkan pada laman website. Bisnis proses pada tahap tracing data produk ditunjukan pada Gambar 10.

\section{Perancangan website}

Desain arsitektur sistem Traceability produk halal berbasis web dengan kerangka sisem digital business ecosystem melibatkan beberapa pengguna website sebagai representasi dari stakholder yang berperan dalam sistem Traceability (Gambar 11).

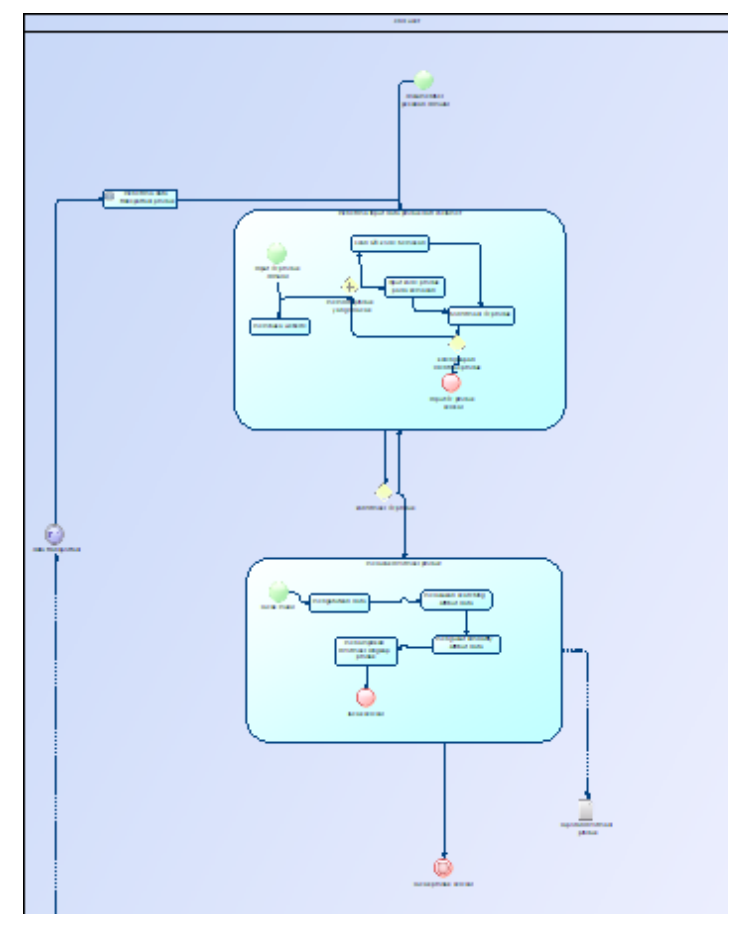

Gambar 10. Proses pelacakan informasi pada sistem traceability

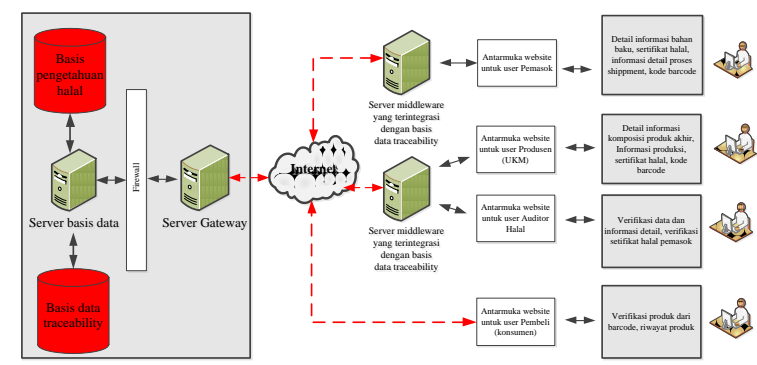

Gambar 11. Detail arsitektur sistem Traceability halal (diadopsi dari Zailani et al. 2010)

Nama domain website yang akan dirancang pada penelitian ini adalah www.halalfoodtraceability.com. Proses 
desain website diawali dengan membuat dummy website berdasarkan misi yang akan dijalankan oleh setiap stakeholder pada analisis kebutuhan. Sistem website traceability ini dirancang sebagai platform basis data secara daring bagi pelaku UKM. Sehingga pengguna utama sistem adalah UKM (User I) yang akan berperan sebagai stakeholder unit produksi dan unit pengiriman. Sementara konsumen merupakan stakeholder yang berperan untuk melakukan pelacakan terhadap produk yang dibeli. Beberapa fitur yang dirancang pada sistem traceability ini diantaranya:

1. Pengumpulan data

Fitur ini terdapat pada tahap registrasi pengguna website bagi UKM (user I) dilakukan dengan pembuatan akun pengguna. Beberapa data yang dibutuhkan untuk mendapatkan akun pengguna diantaranya:

1. Nama Produsen

2. Email

3. Nama Pemilik

4. Pilih tipe izin USAHA (P-IRT, CV, PT)

5. No Izin Usaha*

6. No KTP Pemilik*

7. No HP/Telephone ${ }^{1.0 *}$

8. Nama Facebook

9. Alamat produsen*

10. Data lokasi koordinat produsen ${ }^{1.2 *}$

Data bertanda $\left({ }^{*}\right)$ merupakan data yang harus dimasukan oleh produsen untuk mendukung proses traceability produk. Bentuk interface pada proses registrasi yang telah dirancang dalam bentuk dummy ditunjukan pada Gambar 12.

Tahap registrasi selanjutnya dilakukan dengan mengirim input data terkait peran UKM dalam sistem yaitu pendataan proses produksi dan pengiriman barang. Oleh karenanya UKM akan diminta untuk mengirimkan data pada unit produksi diantaranya:

1. Nomor Sertifikat Halal Produk ${ }^{1.1 *}$ (jika sudah ada)

2. Nama produk ${ }^{1.2}$
3. Data material berikut nomor Sertifikat Halal 1.3

4. Data pemasok ${ }^{1.4}$

5. Data matriks bahan ${ }^{1.5}$

6. Data jumlah Line/batch ${ }^{1.6}$

7. Penanggung jawab line $e^{1.7}$

8. Foto-foto produk

Serta data yang berkaitan dengan data pada unit pengiriman, diantaranya:

1. Data nama toko/retailer 1.8

2. Data alamat toko/retailer ${ }^{1.9}$

3. Data CP Toko/retailer 1.10

4. Data tag koordinat lokasi toko/retailer ${ }^{1.11}$

5. Data Nomor polisi kendaraan UKM $^{1.12}$

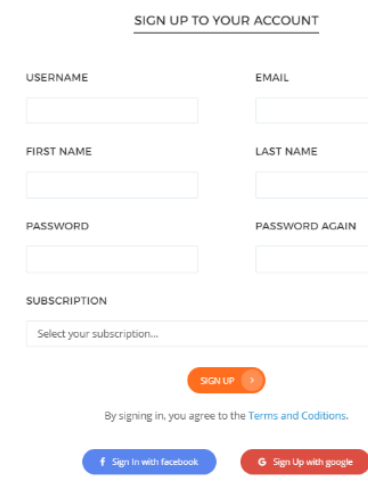

Gambar 12. User interface proses registrasi pelaku UKM

Proses registrasi kemudian diverifikasi oleh stakeholder admin website. Berdasarkan data yang berkaitan dengan proses produksi dan pengiriman produk, sistem akan melakukan generate formulir pendokumentasian. Formulir ini berisi data-data dari user UKM yang terkait dengan unit produksi dan unit pengiriman. Formulir ini akan digunakan untuk dokumentasi data produksi dan pengiriman saat dilapangan. Hasil isian formulir ini yang akan dimasukan ke dalam sistem website, seperti yang dijelaskan pada alur bisnis proses pada Gambar 8. Formulir berisi kode-kode barcode yang dibangkitkan (generate) dari data text atau angka yang dikirimkan user. Admin akan mengirimkan formulir melalui email sebagai indikator bahwa 
proses registrasi sudah terverifikasi, kemudian UKM dapat menggunakan formulir dengan cara mencetak sendiri.

2. Input data

Tahapan input data yang dilakukan dengan mengisi field data pada laman website. Sistem traceability dapat dijalankan dengan keterlibatan digital species (DS) dan traceable unit (TU) (Ginantaka 2015). Digital species merupakan unit perangkat digital yang digunakan untuk menjalankan sistem. Sementara traceable unit merupakan unit terkecil dari pengidentifikasi setiap komponen yang didokumentasikan. Fitur input data dilakukan dengan cara mengisi formulir dokumentasi yang berisi data pilihan data pada unit produksi dan unit pengiriman. Formulir ini merupakan traceable unit (TU 1). Operator lapangan melakukan pemilihan/checklist data berupa data text atau angka dalam formulir yang dilengkapi dengan barcode yang sesuai. Setelah pengisian formulir selesai, operator dapat melakukan proses masukan (input) data pada laman website melalui computer desktop yang merupakan digital species 1 (DS1). Input data dilakukan dengan memindai barcode sesuai yang dipilih operator lapangan menggunakan barcode scanner (Gambar 14) yang merupakan digital species 2 (DS2). Sistem berbasis Digital Business Ecosystem (DBE) membutuhkan kerjasama antar DS sehingga masingmasing DS dapat melakukan sinergi tugas (Hadzic dan Dilon 2007). Matriks data pada unit produksi digambarkan pada Tabel 1.

Setelah proses input data, user I dapat melakukan generate QR-code hasil yang akan dicetak menjadi label produk sebagai Traceable unit 2 (TU2). QR-code diperoleh dengan mengunduh file dari laman website seperti ditunjukan pada Gambar 15. Label QR-code tersebut akan berisi kode ID produk yang dapat digunakan oleh user II untuk proses tracing dengan cara melakukan pemindaian QR-code menggunakan software yang sudah dipasang pada smartphone user II.

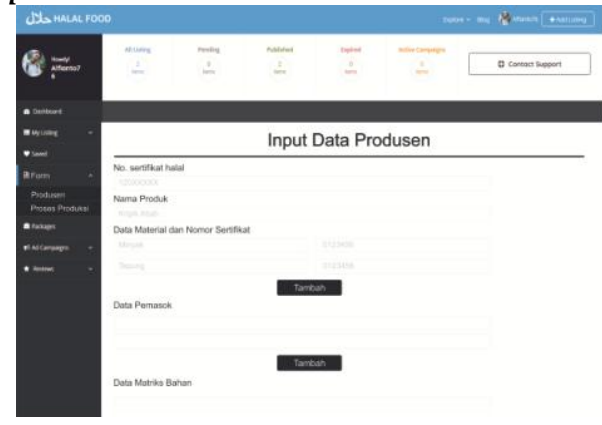

Gambar 14. Interface input data produk bagi user UKM

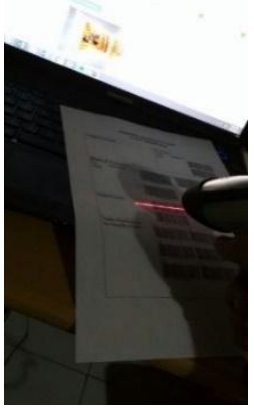

(a)

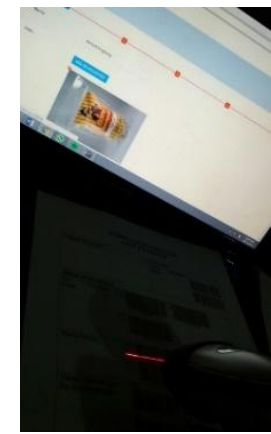

(b)
Gambar 13. (a) Proses pemindaian barcode dan (b) pembacaan oleh barcode scanner kedalam field data pada laman website

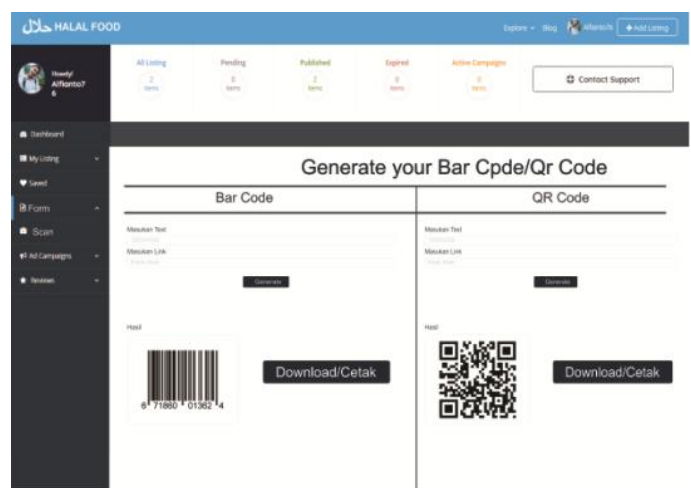

Gambar 15. Contoh bentuk QR-code pada label kemasan

\section{Pelacakan produk}

Fitur ini ditujukan bagi konsumen produk UKM yang merupakan user II untuk mengakses informasi berdasarkan data yang sudah dimasukan dalam database sistem. Setelah mengakses laman website, konsumen dapat 
melakukan alternatif proses pada tahapan pelacakan informasi Alternatif pertama dilakukan dengan cara memindai label (barcode atau QR code) pada kemasan. Alternatif kedua adalah dengan memasukan secara manual kode ID produk pada label kemasan dengan cara mengetik ID produk pada field search engine. Setelah ID produk dimasukan sistem akan mulai melakukan proses pencarian data pada database. 
Tabel 1. Contoh data produksi pada unit produksi

\begin{tabular}{|c|c|c|c|c|c|c|c|c|c|c|c|c|}
\hline \multirow[t]{2}{*}{$\begin{array}{l}\text { Tanggal } \\
\text { Input data }\end{array}$} & \multirow[t]{2}{*}{ Waktu input } & \multirow[t]{2}{*}{ ID produk } & \multirow[t]{2}{*}{ No Sertifikat Halal } & \multicolumn{2}{|c|}{ ID material } & \multirow[t]{2}{*}{$\begin{array}{l}\text { ID } \\
\text { batch/line }\end{array}$} & \multicolumn{2}{|c|}{$\begin{array}{l}\text { ID pemasok } \\
\text { Material }\end{array}$} & \multirow[t]{2}{*}{$\begin{array}{l}\text { Waktu selesai } \\
\text { produksi }\end{array}$} & \multirow[t]{2}{*}{$\begin{array}{l}\text { Waktu } \\
\text { kadaluarsa }\end{array}$} & \multirow[t]{2}{*}{$\begin{array}{l}\text { Jumlah } \\
\text { produk }\end{array}$} & \multirow[t]{2}{*}{$\begin{array}{l}\text { ID } \\
\text { Operator }\end{array}$} \\
\hline & & & & Kode & ID & & Kode & ID & & & & \\
\hline \multirow[t]{8}{*}{$12 / 08 / 2017$} & $01.32 \mathrm{PM}$ & P1910201703 & 00110048090508 & $\mathrm{M}$ & 2 & 31 & $P$ & 003 & $12.30 \mathrm{PM}$ & $12 / 12 / 2017$ & 1487 & 7 \\
\hline & & & & M & 6 & & $\mathrm{P}$ & 001 & & & & \\
\hline & & & & M & 10 & & $P$ & 001 & & & & \\
\hline & & & & M & 8 & & $P$ & 003 & & & & \\
\hline & 05.15 PM & P2110201704 & 00110048091308 & M & 4 & 35 & $\mathrm{P}$ & 003 & $16.20 \mathrm{PM}$ & $12 / 12 / 2017$ & 1432 & 7 \\
\hline & & & & M & 6 & & $\mathrm{P}$ & 001 & & & & \\
\hline & & & & M & 2 & & $\mathrm{P}$ & 003 & & & & \\
\hline & & & & M & 10 & & $\mathrm{P}$ & 001 & & & & \\
\hline \multirow[t]{2}{*}{$14 / 08 / 2017$} & $11.32 \mathrm{AM}$ & P2110201405 & 00110048091308 & M & 5 & 39 & $\mathrm{P}$ & 003 & $10.02 \mathrm{AM}$ & $12 / 12 / 2017$ & 1321 & 9 \\
\hline & & & & M & 3 & & $\mathrm{P}$ & 003 & & & & \\
\hline
\end{tabular}

Informasi yang ditampilkan pada website meliputi informasi proses produksi, informasi retail yang menjual produk serta informasi lokasi produsen. Tampilan lokasi produsen dapat terkoneksi dengan API (application program interface) google maps. Konsumen dapat melakukan pelacakan lokasi dan dapat menggunakan fitur google maps agar dapat menunjukan peta navigasi menuju lokasi produsen. Salah satu output dari sistem traceability adalah dihasilkan dokumen hasil penelusuran yang dapat digunakan oleh user konsumen. Tampilan antarmuka (interface) untuk konsumen ditunjukan seperti pada. Tampilan antarmuka (interface) untuk konsumen ditunjukan seperti pada Gambar 16.

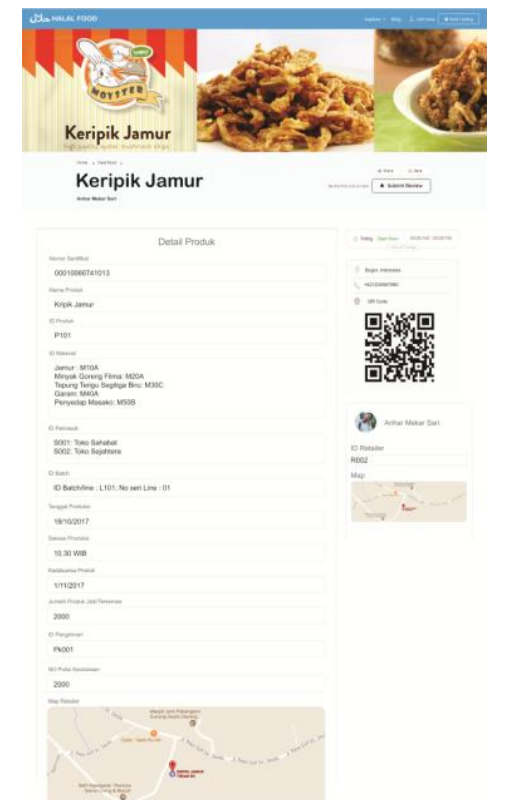

Gambar 16. Interface tracing produk pada website traceability

\section{KESIMPULAN}

Analisis sistem menunjukan bahwa terdapat 4 stakeholder yang berperan dalam sistem traceability produk pangan halal untuk UKM. User 1 merupakan produsen produk pangan yang memiliki dua stakeholder yaitu unit produksi dan unit pengiriman. Setiap stakeholder berperan dalam proses perekaman data produksi dan data pengiriman barang kepada retailer. Penelitian ini telah berhasil merancang website yang dapat mengakomodasi kebutuhan setiap stakeholder. User 2 berupa konsumen dapat mencari informasi yang berkaitan dengan produk pangan yang mereka beli untuk mengecek data lebih detail terkait proses produksi dan kehalalan. Hasil verifikasi dan validasi sistem menunjukan bahwa sistem dapat memenuhi fungsionalitas dan dapat menghasilkan output sesuai yang diharapkan.

\section{UCAPAN TERIMA KASIH}

Peneliti mengucapkan terima kasih kepada Kemenristekdikti yang telah mendukung pendanaan pada penelitian ini. Penelitian ini dibiayai Direktorat Riset dan Pengabdian Masyarakat Direktorat Jenderal Penguatan Riset dan Pengembangan Kementerian Riset, Teknologi dan Pendidikan Tinggi Sesuai dengan Kontrak Penelitian No. 1598/K4/KM/2017 tahun anggaran 2017. 


\section{DAFTAR PUSTAKA}

Bennet GS. 2010. Food Identity Preservation and Traceability. New York (US): CRC Press

Bosona T, Grebesenbet G. 2013. Food Traceability as an integral part of logistics management in food and agricultural supply chain. Food Contr 33:32-48. doi:10.1016/ j.foodcont. 2013.02.004.

Furness A, Osman, KA. 2006. Developing Traceability System Across the Food Supply Chain: An Overview. Di dalam: Furness A, Smith I, editor. Improving Traceability in Food Peocessing. North America (US). Woodhead Publishing Limited. p 3-24

Ginantaka A. 2015. An Analysis and Design of Frozen Vanname Shrimp Product Based on Digital Business Ecosystem. Tesis. Bogor (ID): Institut Pertanian Bogor.

Hadzic M, Dillon TS, Chang E. 2007. Use of Digital Ecosystem and Ontology Technology for Standardization of Medical Records. IEEE DEST: 595601

Hu J, Zhang X, Moga LM. 2012. Modeling and implementation of the vegetable supply chain Traceability system. Food Contr. 30:341353.doi:10.1016/j.foodcont.2012. 06.037

Kendall KE and Kendall JE. 2011. System Analysis and Design. New Jersey (CA): Pearson Education, Inc.

Mgonja JT, Luning P, Van der Vorst JGAJ. 2012. Diagnostic model for assessing Traceability system performance in fish processing plants. J Food Engineer. 118:188197. doi:

10.1016/j.jfoodeng.2013.04.009

Nachira F, Dini P, Nicolai A. 2007. A network of digital business ecosystem for Europe: roots, processes, and perspectives. Di dalam: Nachira F, Nicolai A, Dini P, Louarn ML, Leon LR, editor. Digital Business Ecosystems. Luxembourg: European Commission. p 1-20.

Olsen P dan Borit M. 2013. How to define Traceability. TF Scien \& Technol. 29:142-

150.doi:10.1016/j.tifs.2012.10.003

Shafii Z dan Khadijah WMNWS. 2012. Halal Traceability Framework for Halal Food Production. World Applied Science Journal. 17:01-05.

Scheer FP. 2006. Optimising supply chain using Traceability system. In: Furness $A$, Smith I, editor. Improving Traceability in Food Processing. North America (US). Woodhead Publishing Limited. p 52-64

Thakur M, Donelly KAM. 2010. Modeling Traceability Information in Soy Bean Value Chains. J Food Enginer. 99:98105.doi:10.1016/j.jfoodeng.2010.02. 004

White SA, Miers D. 2008. BPMN Modelling and Reference Guide. Florida (US): Future Strategies, Inc.

Wasson CS. 2006. System Analysis Design and Development. New Jersey (CA): John Wiley \& sons, Inc.

Yang Y dan Bao W. 2010. The Design and Implementation of Halal Beef Wholly Quality Traceability System. IFIP Advances in Information and Communication Technology. 346: 464-472

Zailani S, Arrifin Z, Wahid NA, Othman R, Fernando Y. 2010. Halal Traceability and Halal Tracking System in Strengthening Halal Food Supply Chain for Food Industry in Malaysia (A Review). J Food Technology. 8(3):74-81. 